\title{
Basal Cell Carcinoma Arising from Xeroderma Pigmentosum: A Case Report and an Immunohistochemical Study
}

\author{
Sadanori Furudate Taku Fujimura Gen-ichi Tojo Takahiro Haga \\ Setsuya Aiba \\ Department of Dermatology, Tohoku University Graduate School of Medicine, \\ Sendai, Japan
}

\section{Key Words}

Xeroderma pigmentosum $\cdot$ Basal cell carcinoma $\cdot \mathrm{CD} 163^{+} \cdot \mathrm{M} 2$ macrophages $\cdot$ Foxp3

\begin{abstract}
We describe a 26-year-old Japanese patient with basal cell carcinoma arising from xeroderma pigmentosum (XP). Immunohistochemical staining revealed dense infiltration of $\mathrm{CD}_{163}{ }^{+}$ M2 macrophages, together with Foxp $3^{+}$regulatory T cells. Interestingly, MMP9, which was reported as one of the functional markers for immunosuppressive macrophages, was also detected in the $\mathrm{CD}_{163}{ }^{+} \mathrm{M} 2$ macrophage-infiltrated areas. Our case suggests the immunological background of tumor development in a patient with XP.
\end{abstract}

\section{Introduction}

Xeroderma pigmentosum (XP) is an autosomal recessive disorder characterized by extreme sensitivity to ultraviolet radiation and more than a 1,000-fold increase in the risk of cutaneous malignancy, including basal cell carcinoma (BCC), squamous cell carcinoma, and malignant melanoma in sun-exposed areas [1]. Though previous reports suggest that one of the histopathological findings of XP in the early stage is the variety of infiltrating lymphocytes [2], the precise profiles of these lymphocytes have not been investigated so far.

The roles of regulatory T cells (Tregs) are currently an area of interest in the field of human skin cancer and inextricably connected with immune-tolerance and suppressed

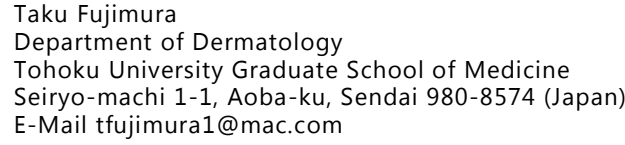


recognition of tumor antigens in tumor progression and recurrence [3-6]. Together with Tregs, immunosuppressive macrophages, such as myeloid-derived suppressor cells, tumorassociated macrophages and $\mathrm{CD}_{163^{+}} \mathrm{M} 2$ macrophages, have recently been shown to contribute to establishing the tumor microenvironment in skin cancer [7-11].

\section{Case Report}

A 26-year-old male Japanese visited our outpatient clinic with a 2-year history of pigmented nodule on his nose. He has had photosensitivity since he was 3-months old and was diagnosed with XP type A. On his initial visit, physical examination revealed a waxy, blackishbrown nodule with telangiectasia on his nose (fig. 1a). The size of the nodule was approximately $7 \times 7 \mathrm{~mm}$ in diameter. The dermatoscopic findings revealed multiple blue-gray globules accompanied by arborizing vessels (fig. 1b). Based on the above findings, we clinically diagnosed this patient as having BCC with XP and excised the tumor with a 2-mm surgical margin from the lesion. The histological findings revealed multiple, palisaded basophilic tumor masses surrounded by prominent infiltrating lymphocytes (fig. 1c), confirming our clinical diagnosis. To further evaluate the profiles of the tumor-infiltrating lymphocytes, we employed immunohistochemical staining for CD8, granulysin, TIA-1, $\mathrm{CD}^{2} 3^{+}$, Foxp3 and MMP-9, as previously reported [12]. Immunohistochemical staining revealed dense infiltration of $\mathrm{CD}^{+}$cells (fig. 2a), $\mathrm{CD} 163^{+} \mathrm{M} 2$ macrophages (fig. $2 \mathrm{~b}$ ) and Foxp3+ cells (fig. 2c). MMP9+ cells were detected in the $\mathrm{CD}^{+} 163^{+} \mathrm{M} 2$ macrophage-infiltrated areas (fig. 2d), and TIA-1+ cells were scattered around the tumor (data not shown). A few granulysin+ cells were detected, mainly in the $\mathrm{CD}^{+}$area (data not shown). The number of immunoreactive cells was counted using an ocular grid of $1 \mathrm{~cm}^{2}$ at a magnification of $\times 400$ (fig. 3). Staining of the infiltrated lymphocytes was examined in more than 5 random, representative fields from each section.

\section{Discussion}

Alternatively activated macrophages, M2 macrophages, have an important role in the responses to parasite infection, tissue remodeling, angiogenesis and tumor progression [13]. Together with Tregs, immunosuppressive macrophages, such as myeloid-derived suppressor cells and $\mathrm{CD} 163^{+} \mathrm{M} 2$ macrophages, promote an immunosuppressive environment in the tumor-bearing host [7-9]. In addition to directly suppressing effector T cells, immunosuppressive macrophages also indirectly suppress effector $\mathrm{T}$ cells by several mechanisms through the induction of Tregs and Th2 polarizations [13]. Another report suggested that M2 macrophages produce thymus and activation-regulated chemokine to induce Th2 cells and Tregs [14].

The potential role of Tregs in human disease is currently the focus of intensive research efforts [15]. Indeed, a recent report describes that a Treg population isolated and expanded from normal human skin highly expressed CD25, L-selectin, GITR, Foxp3 and intracellular CTLA-4 as well as the skin homing addressins CLA, CCR4 and CCR6 [16]. Moreover, RANKL expression by keratinocytes alters the function of epidermal Langerhans cells, resulting in systemic increases of Tregs [17], strongly suggesting that Tregs have a crucial function in various inflammatory skin disorders and skin tumors. Indeed, we previously reported the distribution of Foxp3 ${ }^{+}$Tregs in the lesional skin of psoriasis vulgaris and spongiotic 
dermatitis [12] as well as extramammary Paget's disease [4] and BCC [18], which might suggest a contribution of Tregs to skin tumors.

$\mathrm{XP}$ is a rare autosomal recessive, cancer-prone genodermatosis characterized by a defect in the repair of DNA damage caused by UVR, resulting in a high risk in the development of cutaneous malignancies, including BCCs, squamous cell carcinomas and melanomas on sun-exposed areas [19-21]. Histological criteria of XP are characterized as follows: hyperkeratosis, chronic inflammation in the upper dermis and hyperpigmentation in the early stage, and basophilic degeneration of the collagen and solar elastosis in the upper dermis in the later stage [2]. Though various molecular analyses of the carcinogenesis of XP have been reported previously, and though both $\mathrm{CD} 163^{+} \mathrm{M} 2$ macrophages and Foxp3+ Tregs contribute to the progression of conventional non-XP-derived BCC $[9,18,22]$, to the best of our knowledge, there is no report focusing on the profiles of immunosuppressive cells in tumors developing from XP. Therefore, we hypothesized that immunosuppressive cells, M2 macrophages and Tregs might contribute to the carcinogenesis of BCC arising from XP. In our present case, $\mathrm{CD} 163^{+} \mathrm{M} 2$ macrophages and Foxp3 $3^{+}$Tregs were densely infiltrating around the tumor. In addition, MMP9+ cells, also known as functional markers for immunosuppressive macrophages [7], were detected around the tumor mass. In contrast to immunosuppressive cells, few granulysin ${ }^{+}$cells that lyse various tumors in conjunction with perforin [23] were observed around the tumor. In summary, we described a case of BCC arising from XP. Our present study sheds light on the immunological background of tumor development in a patient with XP.

\section{References}

1 Kraemer KH, Lee MM, Scotto J: Xeroderma pigmentosum. Cutaneous, ocular, and neurologic abnormalities in 830 published cases. Arch Dermatol 1987;123:241-250.

2 Elder DE, Elemenitsas R, Johnson BL Jr, Murphy GF: Lever's Histopathology of the Skin, ed 10. Philadelphia, Lippincott-Raven, 2008.

3 Nishikawa H, Sakaguchi S: Regulatory T cells in tumor immunity. Int J Cancer 2010;127:759-767.

-4 Fujimura T, Kambayashi Y, Hidaka T, Hashimoto A, Haga T, Aiba S: Comparison of Foxp3+ regulatory T-cells and CD163+ macrophages in invasive and non-invasive extramammary Paget's disease. Acta Derm Venereol 2012,92:625-628.

5 Shimizu J, Yamazaki S, Sakaguchi S: Induction of tumor immunity by removing CD25+CD4+ T cells: a common basis between tumor immunity and autoimmunity. J Immunol 1999;163:5211-5218.

6 Sakaguchi S, Sakaguchi N, Shimizu J, Yamazaki S, Sakihama T, Itoh M, et al: Immunologic tolerance maintained by CD25+CD4+ regulatory T cells: their common role in controlling autoimmunity, tumor immunity, and transplantation tolerance. Immunol Rev 2001;182:18-32.

7 Fujimura T, Mahnke K, Enk AH: Myeloid derived suppressor cells and their role in tolerance induction in cancer. J Dermatol Sci 2010;59:1-6.

-8 Pettersen JS, Fuentes-Duculan J, Suárez-Fariñas M, et al: Tumor-associated macrophages in the cutaneous SCC microenvironment are heterogeneously activated. J Invest Dermatol 2011;131:1322-1330.

-9 Tjiu JW, Chen JS, Shun CT, Lin SJ, Liao YH, Chu CY, Tsai TF, Chiu HC, Dai YS, Inoue H, Yang PC, Kuo ML, Jee SH: Tumor-associated macrophage-induced invasion and angiogenesis of human basal cell carcinoma cells by cyclooxygenase-2 induction. J Invest Dermatol 2009;129:1016-1025.

10 Olson MT, Puttgen KB, Westra WH: Angiosarcoma arising from the tongue of an 11-year-old girl with xeroderma pigmentosum. Head Neck Pathol 2012;6:255-257.

11 Sharma S, Deshmukh AD, Bal MM, Chaukar DA, Dcruz AK: Angiosarcoma of the scalp associated with xeroderma pigmentosum. Indian J Med Paediatr Oncol 2012;33:126-129.

12 Fujimura T, Okuyama R, Ito Y, Aiba S: Profiles of Foxp3+ regulatory T cells in eczematous dermatitis, psoriasis vulgaris and mycosis fungoides. Br J Dermatol 2008;158:1256-1263.

13 Satoh T, Takeuchi O, Vandenbon A, Yasuda K, Tanaka Y, Kumagai Y, Miyake T, Matsushita K, Okazaki T, Saitoh T, Honma K, Matsuyama T, Yui K, Tsujimura T, Standley DM, Nakanishi K, Nakai K, Akira S: The Jmjd3-Irf4 axis regulates M2 macrophage polarization and host responses against helminth infection. Nat Immunol 2010;11:936-944. 


\section{Case Reports in Dermatology}

\begin{tabular}{l|l}
\hline Case Rep Dermatol 2013;5:64-68 \\
\hline DOI: $\underline{10.1159 / 000350182}$ & $\begin{array}{l}\text { C 2013 S. Karger AG, Basel } \\
\text { www.karger.com/cde }\end{array}$ \\
\hline
\end{tabular}

Furudate et al.: Basal Cell Carcinoma Arising from Xeroderma Pigmentosum: A Case

Report and an Immunohistochemical Study

14 Jones K, Vari F, Keane C, Crooks P, Nourse JP, Seymour LA, Gottlieb D, Ritchie D, Gill D, Gandhi MK: Serum CD163 and TARC as disease response biomarkers in classical Hodgkin lymphoma. Clin Cancer Res 2013;19:731-742.

15 Baecher-Allan C, Hafler DA: Human regulatory T cells and their role in autoimmune disease. Immunol Rev 2006;212:203-216.

-16 Clark RA, Kupper TS: IL-15 and dermal fibroblasts induce proliferation of natural regulatory T cells isolated from human skin. Blood 2007;109:194-202.

17 Loser K, Mehling A, Loeser S, Apelt J, Kuhn A, Grabbe S, Schwarz T, Penninger JM, Beissert S: Epidermal RANKL controls regulatory T-cell numbers via activation of dendritic cells. Nat Med 2006;12:1372-1379.

18 Fujimura T, Kakizaki A, Kambayashi Y, Aiba S: Basal cell carcinoma with spontaneous regression: a case report and immunohistochemical study. Case Rep Dermatol 2012;4:125-132.

19 Suzuki H, Kalair W, Shivji GM, Wang B, Toto P, Amerio P, Kraemer KH, Sauder DN: Impaired ultraviolet-Binduced cytokine induction in xeroderma pigmentosum fibroblasts. J Invest Dermatol 2001;117:1151-1155.

20 Salerni G, Cecilia N, Cabrini F, Kolm I, Carrera C, Alós L, Malvehy J, Puig S: Plantar basal cell carcinoma in a patient with xeroderma pigmentosum: importance of dermoscopy for early diagnosis of nonpigmented skin cancer. Br J Dermatol 2011;165:1143-1145.

21 Schaffer JV, Orlow SJ: Radiation therapy for high-risk squamous cell carcinomas in patients with xeroderma pigmentosum: report of two cases and review of the literature. Dermatology 2011;223:97-103.

22 Kaporis HG, Guttman-Yassky E, Lowes MA, Haider AS, Fuentes-Duculan J, Darabi K, Whynot-Ertelt J, Khatcherian A, Cardinale I, Novitskaya I, Krueger JG, Carucci JA: Human basal cell carcinoma is associated with Foxp3+ T cells in a Th2 dominant microenvironment. J Invest Dermatol 2007;127:2391-2398.

-23 Krensky AM, Clayberger C: Granulysin: a novel host defense molecule. Am J Transplant 2005;5:1789-1792.
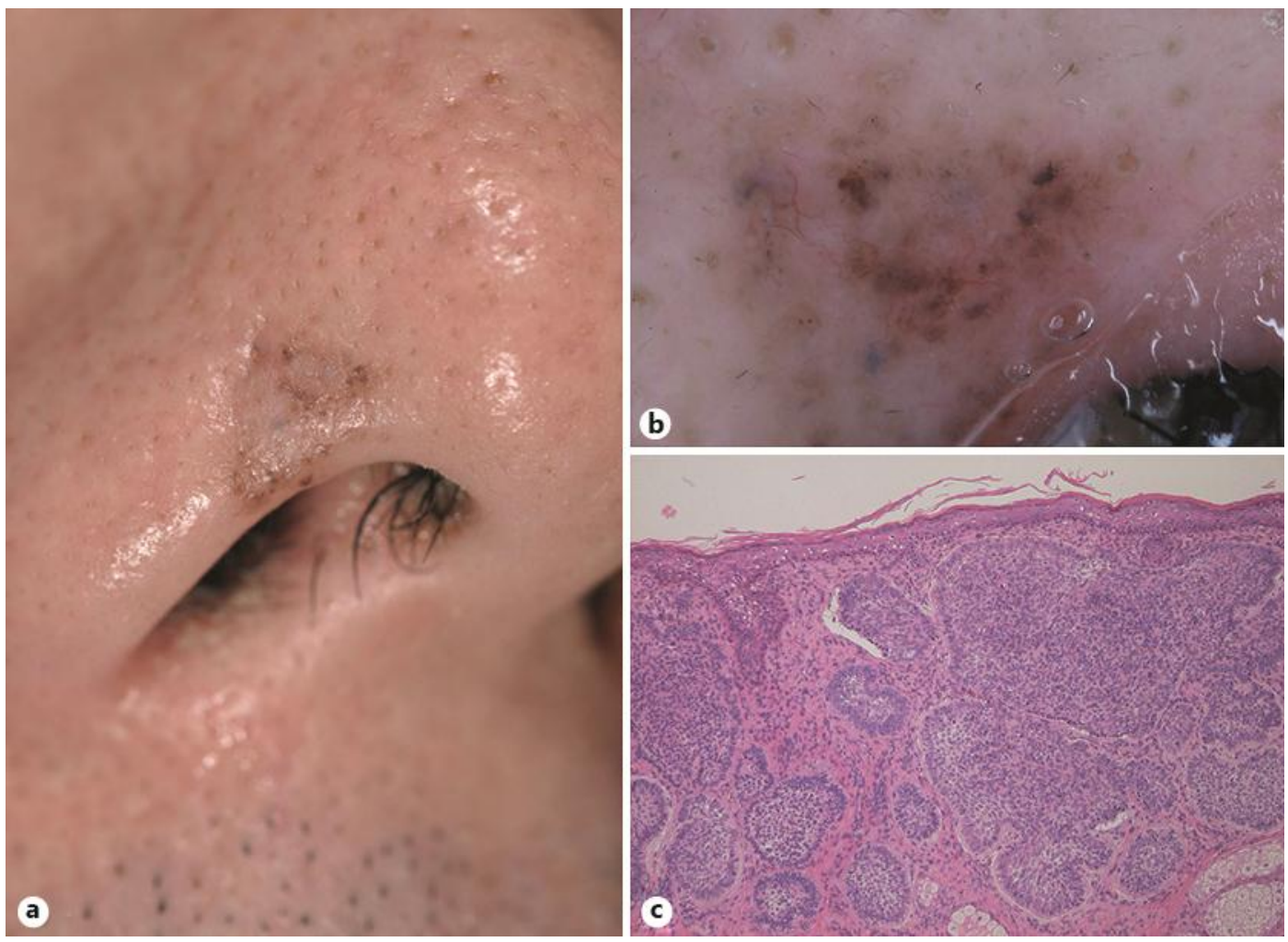

Fig. 1. A waxy, glossy, blackish-brown nodule with telangiectasia on the nose (a). A blue-whitish area with dotted macules is surrounded by arborizing vessels (b). Multiple palisaded basophilic tumor islands are surrounded by infiltrating lymphocytes. Original magnification $\times 100$ (c). 

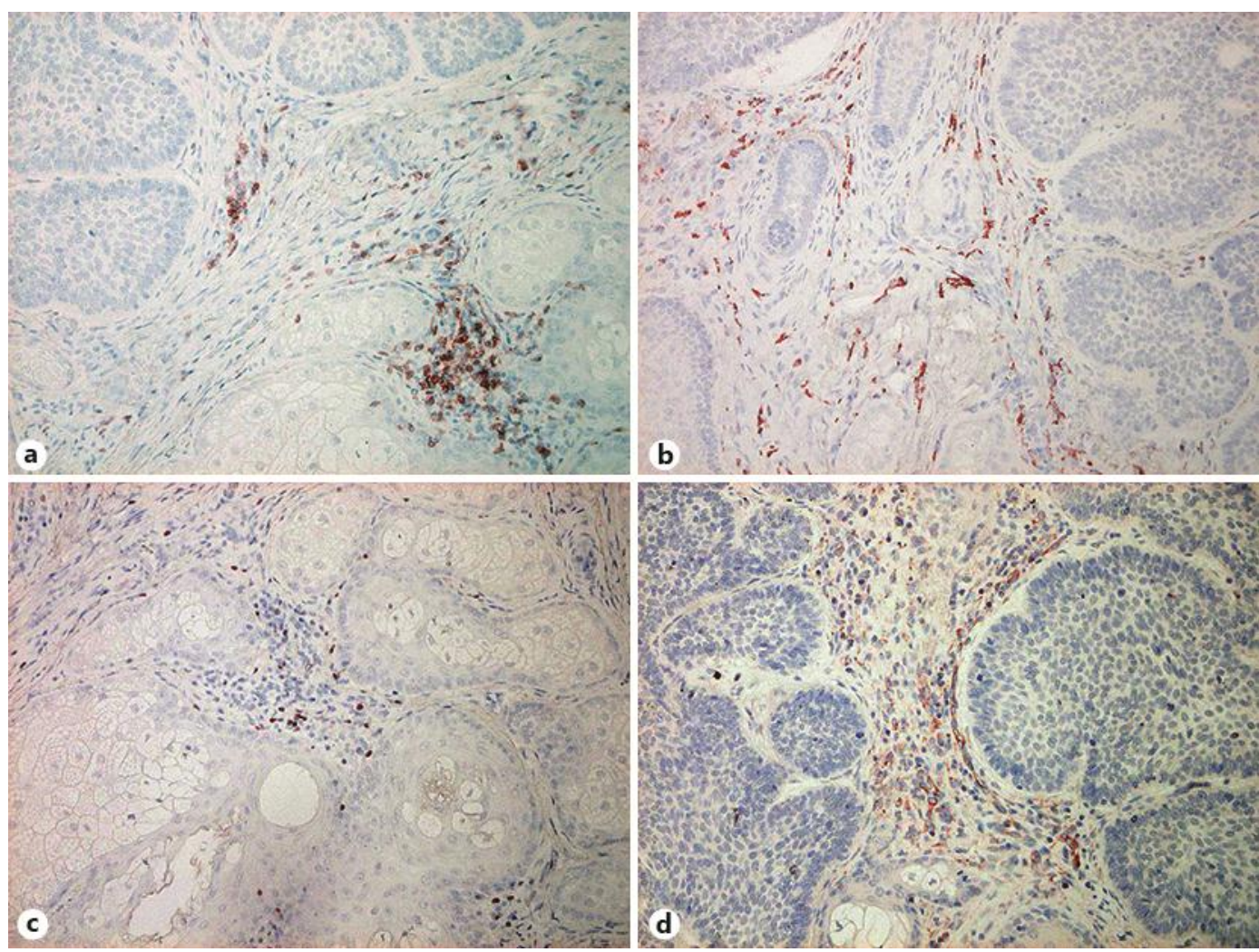

Fig. 2. A paraffin-embedded tissue sample was deparaffinized and stained using anti-CD8 Ab (a), antiCD163 Ab (b), Foxp3 Ab (c) or anti-MMP9 Ab (d). The sections were developed with liquid permanent red. Original magnification $\times 200(a-d)$.

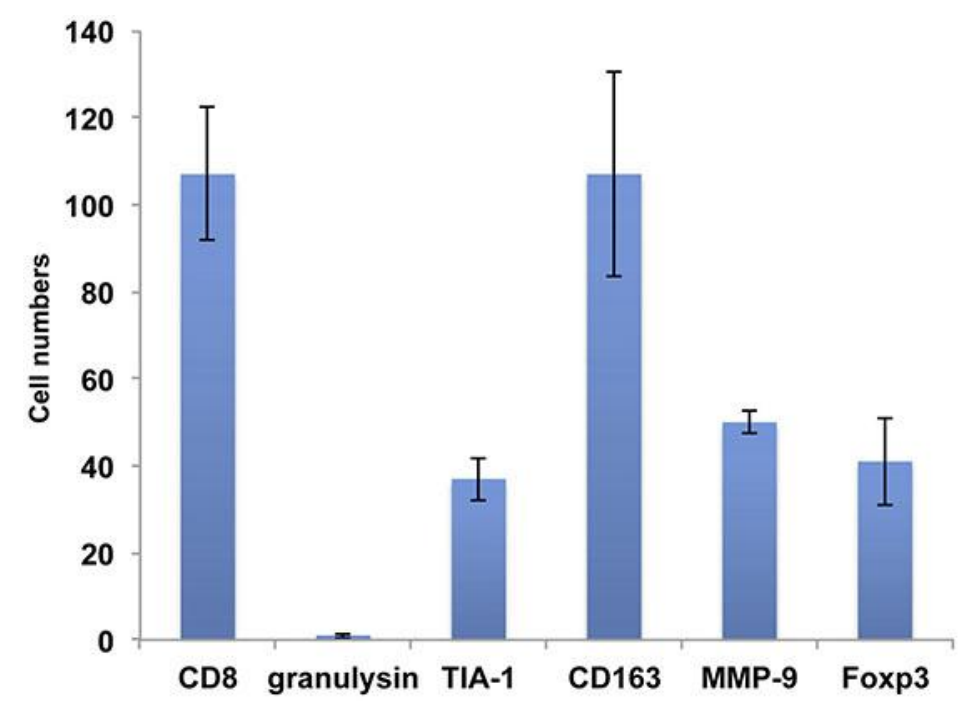

Fig. 3. Summary of the number of immunosuppressive cells versus cytotoxic cells in the tumoral areas. Five representative fields of each section were selected. The number of immunoreactive cells was counted using an ocular grid of $1 \mathrm{~cm}^{2}$ at a magnification of $\times 400$. Data are expressed as the means \pm SD of the number of immunosuppressive cells versus cytotoxic cells in each tumoral area. ${ }^{*} \mathrm{p}<0.05$. 